\title{
PENGENDALIAN PENYEBARAN HAMA KUTU PUTIH (Paracoccus marginatus) PADA TANAMAN DENGAN PENGONTROLAN MODEL KSIRS MENGGUNAKAN METODE MINIMUM PONTRYAGIN
}

\author{
M. Abu' 1 , R. Ratianigsih², A. I. Jaya ${ }^{3}$ \\ 1,2,3 Program Studi Matematika Jurusan Matematika FMIPA Universitas Tadulako \\ Jalan Soekarno-Hatta Km. 09 Tondo, Palu 94118, Indonesia. \\ 1maulidyanisho7992@gmail.com, ${ }^{2,3}$ ratianingsih@yahoo.com
}

\begin{abstract}
Mealybug (Paracoccus marginatus) is one of plants' pest that deploy very easy and very fast, then it can cause death to the plants. This research investigates about the mealybug's deployment control mathematically. Control is done by determining the optimal control of mealybug's deployment model that is by spraying pesticides and the combination of pesticide spraying and control the distance between of the plants. With Pontryagin Minimum method, optimal control solution is determined by solving equation solution state, co-state equation, and the equation for the stationary initial conditions and boundary conditions are given.The results showed that the best control of mealybug's deployment control model is to do the combination of distance between of plants and spraying pesticides at the level of the controller parameters, are $\mathrm{J}_{\mathrm{T}}(\mathrm{t})=\min \left\{\operatorname{maks}\left((0,1),\left(\frac{\beta \mathrm{S}\left(\lambda_{3}-\lambda_{2}\right)}{c_{1}}\right)\right),(0,9)\right\}$ and $P(t)=\min \left\{\operatorname{maks}\left((0,1),\left(\frac{\gamma \operatorname{IR}\left(\lambda_{3}-\lambda_{4}\right)}{c_{2}}\right)\right),(0,9)\right\}$. The results showed that the control is no longer give effect to the decrease of plant population that attacked by mealybug pests after 48 months, although the rate of spraying and the plant has a maximum spacing is $90 \%$.
\end{abstract}

Keywords $\quad$ : Eigenvalues, Jacobian Matrix, Minimum Pontryagin, Paracoccus marginatus, Stability

Abstrak

Kutu Putih (Paracoccus marginatus) merupakan salah satu hama tanaman yang menyebar dengan sangat mudah dan cepat, serta dapat menyebabkan kematian pada tanaman. Penelitian ini mengkaji secara matematis pengendalian penyebaran hama tersebut. Pengendalian dilakukan dengan menentukan kontrol optimal dari model penyebaran hama kutu putih yaitu dengan penyemprotan pestisida dan kombinasi penyemprotan pestisida dan kontrol pengaturan jarak tanaman. Dengan metoda Minimum Pontryagin, solusi optimal kontrol ditentukan dengan menyelesaikan solusi persamaan state, persamaan co-state, dan persamaan stasioner untuk syarat awal dan syarat batas yang diberikan. Hasil penelitian menunjukkan bahwa model pengendalian penyebaran hama kutu putih yang paling baik adalah dengan melakukan kombinasi antara pengaturan jarak tanaman dan penyemprotan pestisida dengan tingkat parameter pengontrolnya yaitu $J_{T}(t)=$ $\min \left\{\operatorname{maks}\left((0,1),\left(\frac{\beta S\left(\lambda_{3}-\lambda_{2}\right)}{c_{1}}\right)\right),(0,9)\right\}$ dan $P(t)=\min \left\{\operatorname{maks}\left((0,1),\left(\frac{\gamma I R\left(\lambda_{3}-\lambda_{4}\right)}{c_{2}}\right)\right),(0,9)\right\}$. Hasil penelitian juga 
memperlihatkan pengendalian tersebut tidak lagi memberikan pengaruh terhadap penurunan populasi tanaman yang terserang hama kutu putih setelah 48 bulan, meskipun tingkat penyemprotan dan pengaturan jarak tanaman sudah maksimum yaitu $90 \%$.

Kata Kunci $\quad$ : Kestabilan, Matriks Jacobi, Minimum Pontryagin, Nilai Eigen, Paracoccus marginatus

\section{PENDAHULUAN}

\subsection{Latar Belakang}

Kutu putih (Paracoccus marginatus)merupakan serangga asli Meksiko/Amerika Tengah. Serangga ini dilaporkan menjadi hama, dan pertama kali ditemukan di Florida pada tahun 1998 (Walker et al., 2003).Menurut Miller dan Miller (2002) hama ini memiliki lebih dari 25 suku tanaman yang bernilai ekonomi sebagai inangnya, di antaranya tanaman pepaya, ubi kayu, jarak pagar, tomat, alpukat melon, dan kembang sepatu. Selain itu, hama ini juga menyerang tanaman mangga, jambu, jagung dan akasia. Hama ini menyebar dengan sangat mudah dan cepat, serta padaserangan berat menyebabkan kematianpada tanaman. Hama ini juga dapat berkembangbiak dengan cepat pada suhu yang panas.

Melalui model matematika yang merepresentasikan penyebaran hama, digambarkan perkembangan banyaknya populasi kelompok tanaman yang rentan terhadap hama (suscepted), kelompok tanaman yang terserang hama (infected), dan kelompok tanaman yang telah bebas hama (recovered). Salah satu model tersebut merupakan model tipe $S I R$ (Suscepted-Infected-Recovered) klasik, dimana model ini telah dikenalkan oleh Kermack dan McKendrick pada tahun 1927.

Penelitian ini mengkaji model pengendalian hama kutu putih secara kimiawi (pestisida) dan secara teknis dengan pengaturan jarak tanaman yang baik. Dalam penelitian ini dibangun model $K S I R$ dimana kelompok populasi kutu putih yang berpotensi menyerang tanaman $(K)$ berinteraksi dengan populasi tanaman yang rentan terhadap hama kutu putih $(S)$, sedemikian hingga sebagian dari kelompok populasi $S$ terserang hama kutu putih sehingga memasuki kelompok populasi tanaman terinfeksi (I). Sebagian dari kelompok populasi ini selanjutnya dapat terbebas dari kutu putih dan memasuki kelompok populasi recovered $(R)$. Pengontrolan selanjutnya dilakukan pada kelompok populasi $S$ dengan pengaturan jarak tanaman $\left(J_{T}\right)$, dan pada kelompok populasi / dikontrol penyemprotan pestisida. Melalui ketiga pengontrolan tersebut diharapkan penyebaran hama kutu putih dapat dikendalikan. Untuk mengoptimalkan pengontrolan yang dilakukan pada hama kutu putih, maka digunakan metoda Minimum Pontryagin.Prinsip minimum Pontryagin merupakan suatu kondisi sehingga dapat memperoleh penyelesaian kontrol optimal yang sesuai dengan tujuan (meminimumkan 
performance index).Prinsip ini dapat digunakan untuk menyelesaikan persamaan linier dan nonlinier.

\subsection{Rumusan Masalah}

Berdasarkan pemaparan latar belakang tersebut, maka pokok permasalahan yang dikemukakan dalam penelitian ini adalah:

Bagaimana menentukan pengontrolan yang optimal pada model matematika pengendalian penyebaran hama kutu putih (Paracoccus marginatus) dengan menggunakan metoda Minimum Pontryagin.

\subsection{Tujuan Penelitian}

Penelitian ini bertujuan untuk mendapatkan pengontrolan yang optimal pada model matematika pengendalian penyebaran hama kutu putih (Paracoccus marginatus) dengan menggunakan metoda Minimum Pontryagin.

\subsection{Manfaat Penelitian}

Manfaat yang diharapkan dalam penelitian ini adalah :

1. Hasil yang diperoleh dapat memberikan informasi tentang metode pengontrolan yang optimal pada model matematika pengendalian penyebaran hama kutu putih (Paracoccus marginatus).

2. Membantu dalam meminimalisir penyebaran hama kutu putih (Paracoccus marginatus).

3. Dapat dijadikan sebagai referensi pengendalian hama pada tanaman.

4. Secara umum untuk mengembangkan ilmu matematika, khususnya pada bidang matematika biologi yang diterapkan pada masalah-masalah pertanian.

\subsection{Asumsi Penelitian}

Adapun asumsi yang digunakan dalam penelitian ini adalah :

1. Jumlah populasi tanaman tetap.

2. Jumlah populasi tanaman dan kutu putih (Paracoccus marginatus) bergantung pada waktu (bulan).

\section{METODE PENELITIAN}

Penelitian dilakukan sesuai prosedur di bawah ini:

a. Melakukan tinjauan pustaka.

b. Merancang model KSIRS merepresentasikan interaksi variabel-variabel penelitian. 
c. Menguji kestabilan model KSIRS. Jika model KSIRS stabil, maka dilakukan redesain model. Kemudian model tersebut akan diuji kestabilannya.

d. Jika model KSIRS tidak stabil, maka dilakukan desain pengontrol. Kemudian menguji apakah populasi tanaman yang terinfeksi pada model dengan pengontrol $I_{p}$ lebih baik dibandingkan populasi tanaman yang terinfeksi pada model tanpa pengontrol $I_{t p}$.

e. Jika $I_{t p}>I_{p}$, maka akan ditarik kesimpulan.

f. Jika $I_{t p}<I_{p}$, maka dilakukan redesain pengontrol.

g. Menyimpulkan hasil penelitian.

III. HASIL DAN PEMBAHASAN

\subsection{Hasil Penelitian}

Penelitian ini merupakan tinjauan matematis dalam pengendalian penyebaran hama kutu putih (Paracoccus marginatus) yang dilakukan dengan menentukan kajian pengontrol optimal dari model matematika penyebaran tersebut. Model penyebaran hama kutu putih (Paracoccus marginatus) dibangun sebagai berikut.

\subsubsection{Model KSIRS}

Penyebaran hama kutu putih dalam penelitian ini dianalogikan sebagai masalah penyebaran penyakit menular. Penyebaran hama kutu putih tentu saja dipengaruhi oleh pertumbuhan populasi kutu putih itu sendiri. Oleh karena itu diperlukan penambahan kompartemen Kyang mengacu pada kompartemen kutu putih secara alami ke dalam kompartemen epidemi dasar SIRS. Dengan demikian kompartemen penyebaran hama kutu putih sebagai berikut.

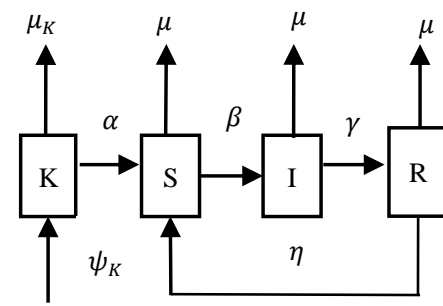

Gambar 1 : Kompartemen KSIRS

Model penyebaran kutu putih (Paracoccus marginatus) dibangun berdasarkan kompartemen pada Gambar 1 sebagai berikut.

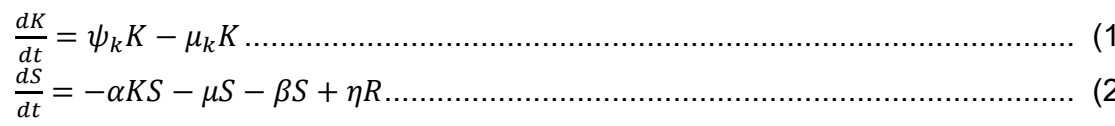


$\frac{d I}{d t}=\beta S-\mu I-\gamma I$
$\frac{d R}{d t}=\gamma I-\mu R-\eta R$

dengan :

$K \quad$ : populasi kutu putih yang berpotensi menyebarkan penyakit

$S$ : populasi tanaman yang berpotensi terserang kutu putih

I : populasi tanaman yang terserang hama kutu putih

$R \quad$ : populasi tanaman bebas hama kutu putih

$\psi_{K}$ : laju kelahiran kutu putih

$\mu_{K}$ : laju kematian kutu putih

$\alpha \quad$ : laju infeksi hama kutu putih ke populasi tanaman

$\mu$ : laju kematian populasi tanaman

$\beta$ : koefisien transmisi hama kutu putih

$\gamma \quad$ : laju penyembuhan dari tanaman terserang hama kutu putih

$\eta$ : laju rekruitmen tanaman yang terbebas hama kutu putih menjadi kelompok rentan.

dengan $\psi_{K}, \mu_{K}, \alpha, \beta, \gamma, \eta, \mu>0$.

\subsubsection{Uji Kestabilan Model}

Fenomena penyebaran hama kutu putih pada tanaman dengan pertumbuhan populasi kutu putih yang tak terkendali secara matematis ditunjukkan dengan ketidakstabilan solusi sistem persamaan yang dibangun oleh persamaan (1) - (4).

\section{a. Penentuan Titik Kritis}

Titik kritis dari sistem persamaan (1) - (4) dapat diperoleh dengan meninjaunya pada keadaan stagnan, yaitu dengan menentukan :

$\frac{d K}{d t}=0, \frac{d S}{d t}=0, \frac{d I}{d t}=0, \frac{d R}{d t}=0$.

Sehingga dapat dinyatakan

$\frac{d K}{d t}=K\left(\psi_{k}-\mu_{k}\right)=0$

$\frac{d S}{d t}=S(-\alpha K-\mu-\beta)+\eta R=0$

$\frac{d I}{d t}=\beta S-I(\mu+\gamma)=0$

$\frac{d R}{d t}=\gamma I-R(\mu+\eta)=0$

Mengingat $\psi_{k}-\mu_{k} \neq 0$, maka sehingga persamaan (6) memberikan $K=0$. Substitusi $K=0$ ke persamaan (7) memberikan:

$S(-\mu-\beta)+\eta R=0$

Karena $(-\mu-\beta) \neq 0$, maka untuk $R \neq 0$, persamaan (9) memberikan $S=\frac{\eta R}{\mu+\beta}$. 
Substitusi $S=\frac{\eta R}{\mu+\beta}$ ke persamaan (7) memberikan :

$I=\frac{\beta \eta R}{(\mu+\beta)(\mu+\gamma)}$

Untuk $R \neq 0$, bernilai sebarang $R=\delta$, diperoleh titik kritis model penyebaran hama kutu putih (Paracoccus marginatus) yaitu $T=\left(0, \frac{\eta \delta}{\mu+\beta}, \frac{\beta \eta \delta}{(\mu+\beta)(\mu+\gamma)}, \delta\right)$.

Dari persamaan (8) dengan $R=\delta$ memberikan :

$I=\frac{\delta(\mu+\eta)}{\gamma}$

Ekivalensi persamaan (11) dan persamaan (12) memberikan :

$\frac{\beta \eta \delta}{(\mu+\beta)(\mu+\gamma)}=\frac{\delta(\mu+\eta)}{\gamma}$

Persamaan (13) memberikan persamaan derajat tiga dalam $\mu$ sebagai berikut.

$\mu\left(\mu^{2}+\mu(\beta+\gamma+\eta)+\beta \eta+\gamma \eta+\beta \gamma\right)=0$

Mengingat $\mu>0$, maka akar - akar persamaan (14) memenuhi :

$$
\begin{aligned}
\mu_{1,2} & =\frac{-b \pm \sqrt{b^{2}-4 a c}}{2 a} \\
& =\frac{-(\beta+\gamma+\eta) \pm \sqrt{(\beta+\gamma+\eta)^{2}-4(\beta \eta+\gamma \eta+\beta \gamma)}}{2} \\
& =\frac{-(\beta+\gamma+\eta) \pm \sqrt{\beta^{2}+\gamma^{2}+\eta^{2}-2(\beta \eta+\gamma \eta+\beta \gamma)}}{2} \ldots \ldots \ldots \ldots \ldots \ldots \ldots \ldots \ldots \ldots \ldots \ldots \ldots \ldots \ldots
\end{aligned}
$$

Nilai $\mu$ yang positif dipenuhi oleh :

$\mu=\frac{-(\beta+\gamma+\eta)+\sqrt{\beta^{2}+\gamma^{2}+\eta^{2}-2(\beta \eta+\gamma \eta+\beta \gamma)}}{2}$

Dengan kalkulasi matematik sederhana dari persamaan (16) diperoleh sebagai berikut

$\left|\sqrt{\beta^{2}+\gamma^{2}+\eta^{2}-2(\beta \eta+\gamma \eta+\beta \gamma)}\right|<1$ dan $|\beta+\gamma+\eta|<1$.

Persamaan (17) dijadikan sebagai dasar pengambilan nilai - nilai $\beta, \gamma$, dan $\eta$ yang digunakan dalam simulasi.

\section{b. Analisis Kestabilan Sistem}

Mengingat titik kritis $T=\left(0, \frac{\eta \delta}{\mu+\beta}, \frac{\beta \eta \delta}{(\mu+\beta)(\mu+\gamma)}, \delta\right)$ bukan titik kritis nol, maka analisa kestabilan dilakukan dengan terlebih dahulu melakukan transformasi. Transformasi tersebut memberikan titik kritis baru $(0,0,0,0)$ dalam sistem koordinat yang baru $(K, s, i, r)$.

$S=\frac{\eta(\delta+r)}{\mu+\beta} \Rightarrow S=\frac{\eta(\delta+r)}{\mu+\beta}+S$

$I=\frac{\beta \eta(\delta+r)}{(\mu+\beta)(\mu+\gamma)} \Rightarrow I=\frac{\beta \eta(\delta+r)}{(\mu+\beta)(\mu+\gamma)}+i$

$R=\delta+r$

Sehingga SPD baru dalam $(K, s, i, r)$ diperoleh dengan substitusi $K, s, i, r$ pada persamaan (5)-(8) sebagai berikut :

$$
\begin{aligned}
& \frac{d K}{d t}=F(K, s, i, r)=K\left(\psi_{k}-\mu_{k}\right) \\
& \frac{d Y}{d t}=G(K, s, i, r)=\left(\frac{\eta(\delta+r)}{\mu+\beta}+s\right)(-\alpha K-\mu-\beta)+\eta(\delta+r) \\
& \frac{d I}{d t}=H(K, s, i, r)=\beta\left(\frac{\eta(\delta+r)}{\mu+\beta}+s\right)-\left(\frac{\beta \eta(\delta+r)}{(\mu+\beta)(\mu+\gamma)}+i\right)(\mu+\gamma)
\end{aligned}
$$


$\frac{d R}{d t}=I(K, s, i, r)=\gamma\left(\frac{\beta \eta(\delta+r)}{(\mu+\beta)(\mu+\gamma)}+i\right)-(\delta+r)(\mu+\eta)$

Matriks Jacobian sebagai hampiran linier dari SPD tidak linier dalam persamaan (21)-(24), diperoleh:

$$
\begin{aligned}
& J=\left(\begin{array}{cccc}
F_{K} & F_{s} & F_{i} & F_{r} \\
G_{K} & G_{s} & G_{i} & G_{r} \\
H_{K} & H_{s} & H_{i} & H_{r} \\
I_{K} & I_{S} & I_{i} & I_{r}
\end{array}\right)_{(0,0,0,0)} \\
& J_{0}=\left(\begin{array}{cccc}
\psi_{K}-\mu_{K-\alpha}\left(\frac{\eta(\delta+r)}{\mu+\beta}\right) & 0 & 0 \\
0 & -\mu-\beta & 0 & -\frac{\mu \eta}{\mu+\beta}-\frac{\beta \eta}{\mu+\beta}+\eta \\
0 & \beta & -\mu-\gamma \frac{\beta \eta}{\mu+\beta}-\frac{\mu \beta \eta}{(\mu+\beta)(\mu+\gamma)}-\frac{\gamma \beta \eta}{(\mu+\beta)(\mu+\gamma)} \\
0 & 0 & \gamma & \frac{\gamma \beta \eta}{(\mu+\beta)(\mu+\gamma)}-\mu-\eta
\end{array}\right)
\end{aligned}
$$

Nilai eigen $(\lambda)$ dari matriks Jacobian ditentukan melalui $\operatorname{det}\left(J_{0}-\lambda I\right)=0$ sebagai berikut

$$
\operatorname{det}\left(\begin{array}{cccc}
\psi_{K}-\mu_{K}-\lambda-\alpha\left(\frac{\eta(\delta+r)}{\mu+\beta}\right) & 0 & 0 \\
0 & -\mu-\beta-\lambda & 0 & -\frac{\mu \eta}{\mu+\beta}-\frac{\beta \eta}{\mu+\beta}+\eta \\
0 & \beta & -\mu-\gamma-\lambda \frac{\beta \eta}{\mu+\beta}-\frac{\mu \beta \eta}{(\mu+\beta)(\mu+\gamma)}-\frac{\gamma \beta \eta}{(\mu+\beta)(\mu+\gamma)} \\
0 & 0 & \gamma & \frac{\gamma \beta \eta}{(\mu+\beta)(\mu+\gamma)}-\mu-\eta-\lambda
\end{array}\right)=0
$$

Dengan menggunakan Metode Kofaktor, diperoleh persamaan karakteristik sebagai berikut.

$\left(\psi_{K}-\mu_{K}-\lambda\right)\left((-\mu-\beta-\lambda)(-\mu-\gamma-\lambda)(-\mu-\eta-\lambda)+\beta \gamma\left(-\frac{\mu \eta}{\mu+\beta}-\frac{\beta \eta}{\mu+\beta}+\eta\right)-\right.$

$\left.\gamma\left(\frac{\beta \eta}{\mu+\beta}-\frac{\mu \beta \eta}{(\mu+\beta)(\mu+\gamma)}-\frac{\gamma \beta \eta}{(\mu+\beta)(\mu+\gamma)}\right)(-\mu-\beta-\lambda)\right)=0$

Dari persamaan (25) diperoleh nilai - nilai eigen $\lambda_{1}, \lambda_{2}, \lambda_{3}$, dan $\lambda_{4}$ sebagai berikut :

$\lambda_{1}=\psi_{K}-\mu_{K}$

$\lambda_{2}=-\mu-\beta$

$\lambda_{3}=-\mu-\gamma$

$\lambda_{4}=-\frac{\mu\left(\mu^{2}+\mu \gamma+\mu \beta+\gamma \beta+\mu \eta+\eta \gamma+\beta \eta\right)}{\mu^{2}+\mu \gamma+\mu \beta+\gamma \beta}$

Tiga nilai eigen yaitu $\lambda_{2}, \lambda_{3}$, dan $\lambda_{4}$ memberikan nilai negatif, sehingga kestabilan model ditentukan melalui nilai eigen pertamanya. Model akan tidak stabil jika $\lambda_{1}$ bernilai positif yang memberikan $\psi_{K}>\mu_{K}$. Kondisi ini terjadi bila laju kelahiran kutu putih lebih besar dari laju kematiannya.

\subsubsection{Desain Pengontrol}

Dalam hal model tidak stabil, maka untuk mengatasi penyebaran hama kutu putih yang tidak terkendali penyemprotan insektisida dan pengaturan jarak tanaman merupakan dua hal yang selama ini dilakukan. Hal tersebut merupakan upaya 
pengendalian hama kutu putih secara kimia dan secara teknis. Secara matematis masalah pengendalian hama kutu putih direpresentasikan melalui parameter $J_{T}$ sebagai pengaturan jarak tanaman, dan $P$ sebagai penentuan penyemprotan terhadap tanaman yang terserang hama kutu putih. Dalam penelitian ini, desain pengontrol dikaji sebagai berikut.

\section{a. Pengontrolan dengan Penyemprotan $(P)$}

Pengendalian hama kutu putih (Paracoccus marginatus) melalui pengontrolan pada persamaan (4.1) - (4.4) dilakukan dengan menempatkan parameter pengontrol $P$ pada persamaan (4.3) dan (4.4) sebagai berikut.

$$
\begin{aligned}
& \frac{d K}{d t}=\psi_{k} K-\mu_{k} K \ldots \ldots \ldots \ldots \ldots \ldots \ldots \ldots \ldots \ldots \\
& \frac{d S}{d t}=-\alpha K S-\mu S-\beta S+\eta R \\
& \frac{d I}{d t}=\beta S-\mu I-P \gamma I \ldots \ldots \ldots \ldots \ldots \ldots \ldots \ldots \\
& \frac{d R}{d t}=P \gamma I-\mu R-\eta R
\end{aligned}
$$

b. Pengontrolan dengan Pengaturan Jarak Tanaman $\left(J_{T}\right)$ dan Penyemprotan $(P)$

Pengendalian hama kutu putih (Paracoccus marginatus) melalui pengontrolan pada persamaan (1) - (4) dilakukan dengan menempatkan parameter pengontrol $J_{T}$ pada persamaan (2) dan parameter pengontrol $P$ pada persamaan (3) dan (4) sebagai berikut.

$$
\begin{aligned}
& \frac{d K}{d t}=\psi_{k} K-\mu_{k} K \\
& \frac{d S}{d t}=-\alpha K S-\mu S-\left(1-J_{T}\right) \beta S+\eta R \\
& \frac{d I}{d t}=\left(1-J_{T}\right) \beta S-\mu I-P \gamma I \\
& \frac{d R}{d t}=P \gamma I-\mu R-\eta R
\end{aligned}
$$

\subsubsection{Penyelesaian Optimal Kontrol}

Pada penyelesaian optimal kontrol ini dibangun suatu performance index pengendalian penyebaran hama kutu putih (Paracoccus marginatus) pada tanaman dengan tujuan meminimalkan banyaknya populasi tanaman yang terinfeksi I. Dalam menentukan penyelesaian optimal kontrol diperlukan kondisi batas dan syarat awal sebagai berikut :

$0<t<t_{f} \quad 0,1 \leq J_{T} \leq 0,9 \quad 0,1 \leq P \leq 0,9$

$K(0)=K_{0} \geq 0, \quad S(0)=S_{0} \geq 0, \quad I(0)=I_{0} \geq 0, \quad R(0)=R_{0} \geq 0$

a. Performance Index untuk Pengontrol dengan Penyemprotan $(P)$

Performance index untuk pengontrol penyemprotan $(P)$ adalah sebagai berikut :

$J\left[u_{2}\right]=\frac{1}{2} \int_{0}^{T}\left(c_{1} P^{2}+c_{2} I^{2}\right) d t$ 
Untuk meminimumkannya, metoda Minimum Pontryagin menyatakan penentuan fungsi Hamiltonian sebagai berikut :

$H=f(x, P, t)+\lambda g(x, P, t)$

$H=\frac{1}{2}\left[c_{1} P^{2}+c_{2} I^{2}\right]+\lambda_{1}\left[\psi_{k} K-\mu_{k} K\right]+\lambda_{2}[-\alpha K S-\mu S-\beta S+\eta R]+\lambda_{3}[\beta S-\mu I-P \gamma I]+$ $\lambda_{4}[P \gamma I-\mu R-\eta R]$

Penyelesaian optimal kontrol dengan penyemprotan $(P)$ diperoleh dengan melalui persamaan state, co-state, dan kondisi stasioner sebagai berikut :

\section{Persamaan State}

Dari persamaan (38) diturunkan persamaan state, sebagai berikut :

$\dot{K}=\frac{\partial H}{\partial \lambda_{1}}=\psi_{k} K-\mu_{k} K$

$\dot{S}=\frac{\partial H}{\partial \lambda_{2}}=-\alpha K S-\mu S-\beta S+\eta R$

$\dot{I}=\frac{\partial H}{\partial \lambda_{3}}=\beta S-\mu I-P \gamma I$

$\dot{R}=\frac{\partial H}{\partial \lambda_{4}}=P \gamma I-\mu R-\eta R$

\section{- Persamaan Co-State}

Dari persamaan (38) diturunkan persamaan co-state, sebagai berikut :

$\dot{\lambda}_{1}=-\frac{\partial H}{\partial K}=-\lambda_{1}\left(\psi_{k}-\mu_{k}\right)+\lambda_{2}(\alpha S)$

$\dot{\lambda}_{2}=-\frac{\partial H}{\partial S}=-\lambda_{2}(-\alpha K-\mu-\beta)-\lambda_{3} \beta$.

$\dot{\lambda}_{3}=-\frac{\partial H}{\partial I}=-c_{2} I-\lambda_{3}(-\mu-P \gamma)-\lambda_{4} P \gamma$

$\dot{\lambda}_{4}=-\frac{\partial H}{\partial R}=-\lambda_{2} \eta-\lambda_{4}(-\mu-\eta)$

\section{Kondisi Stasioner}

Dari persamaan (38) diturunkan persamaan kondisi stasioner, sebagai berikut :

$$
\begin{aligned}
& \frac{\partial H}{\partial P}=0 \Leftrightarrow c_{1} P-\lambda_{3} \gamma I+\lambda_{4} \gamma I=0 \\
& \Leftrightarrow P=\frac{\gamma I\left(\lambda_{3}+\lambda_{4}\right)}{c_{1}}
\end{aligned}
$$

Sehingga diperoleh

$$
P(t)=\min \left\{\operatorname{maks}\left(0,1,\left(\frac{\gamma I\left(\lambda_{3}+\lambda_{4}\right)}{c_{1}}\right)\right), 0,9\right\}
$$

b. Performance Index untuk Pengontrolan dengan Penyemprotan $(P)$ dan Jarak Tanaman $\left(J_{T}\right)$

Pada penyelesaian optimal kontrol menggunakan metode ini akan ditunjukkan pengaturan jarak tanaman $\left(J_{T}\right)$ dan penyemprotan $(P)$ pada tanaman yang optimal dengan tujuan untuk meminimalkan /dengan performanceindex sebagai berikut : 
$J\left[J_{T}, P\right]=\frac{1}{2} \int_{0}^{T}\left(c_{1} J_{T}^{2}+c_{2} P^{2}+c_{3} I^{2}\right) d t$

Model tersebut dapat diselesaikan dengan menggunakan optimal kontrol dimana variabel kontrolnya adalah jarak tanaman $\left(J_{T}\right)$ yang menyatakan kontrol jarak tanaman dan penyemprotan $(P)$ yang menyatakan banyaknya penyemprotan pada tanaman yang terserang hama kutu putih. Sistem dinamiknya adalah sebagai berikut :

$\frac{d K}{d t}=\psi_{k} K-\mu_{k} K$

$\frac{d S}{d t}=-\alpha K S-\mu S-\left(\beta-\beta J_{T}\right) S+\eta R$

$\frac{d I}{d t}=\left(\beta-\beta J_{T}\right) S-\mu I-P \gamma I$

$\frac{d R}{d t}=P \gamma I-\mu R-\eta R$

Untuk meminimumkannya, metoda Minimum Pontryagin menyatakan penentuan fungsi Hamiltonian sebagai berikut :

$H=f\left(x, J_{T}, t\right)+\lambda g\left(x, J_{T}, t\right)$

$H=\frac{1}{2}\left[c_{1} J_{T}{ }^{2}+c_{2} u_{2}{ }^{2}+c_{3} I^{2}\right]+\lambda_{1}\left[\psi_{k} K-\mu_{k} K\right]+\lambda_{2}\left[-\alpha K S-\mu S-\left(\beta-\beta J_{T}\right) S+\eta R\right]+$ $\lambda_{3}\left[\left(\beta-\beta J_{T}\right) S-\mu I-P \gamma I\right]+\lambda_{4}[P \gamma I-\mu R-\eta R]$

Penyelesaian optimal kontrol dengan penyemprotan $(P)$ diperoleh dengan melalui persamaan state, co-state, dan kondisi stasioner sebagai berikut :

\section{Persamaan State}

Dari persamaan (53) diturunkan persamaan state, sebagai berikut :

$$
\begin{aligned}
& \dot{K}=\frac{\partial H}{\partial \lambda_{1}}=\psi_{k} K-\mu_{k} K \\
& \dot{S}=\frac{\partial H}{\partial \lambda_{2}}=-\alpha K S-\mu S-\left(\beta-\beta J_{T}\right) S+\eta R \\
& \dot{I}=\frac{\partial H}{\partial \lambda_{3}}=\left(\beta-\beta J_{T}\right) S-\mu I-P \gamma I \\
& \dot{R}=\frac{\partial H}{\partial \lambda_{4}}=P \gamma I-\mu R-\eta R
\end{aligned}
$$

\section{Persamaan Co-State}

Dari persamaan (53) diturunkan persamaan co-state, sebagai berikut :

$\dot{\lambda}_{1}=-\frac{\partial H}{\partial K}=-\lambda_{1}\left(\psi_{k}-\mu_{k}\right)+\lambda_{2} \alpha S$

$\dot{\lambda}_{2}=-\frac{\partial H}{\partial S}=-\lambda_{2}\left(-\alpha K-\mu-\beta+\beta J_{T}\right)-\lambda_{3}\left(\beta-\beta J_{T}\right)$

$\dot{\lambda}_{3}=-\frac{\partial H}{\partial I}=-c_{3} I-\lambda_{3}(-\mu-P \gamma)-\lambda_{4} P \gamma$

$\dot{\lambda}_{4}=-\frac{\partial H}{\partial R}=-\lambda_{2} \eta-\lambda_{4}(-\mu-\eta)$

\section{Kondisi Stasioner}

Dari persamaan (53) diturunkan persamaan kondisi stasioner, sebagai berikut : $\frac{\partial H}{\partial J_{T}}=0 \Leftrightarrow c_{1} J_{T}+\lambda_{2} \beta S-\lambda_{3} \beta S=0$ 


$$
\begin{aligned}
& \Leftrightarrow J_{T}=\frac{\beta S\left(\lambda_{3}-\lambda_{2}\right)}{c_{1}} \\
& \frac{\partial H}{\partial P}=0 \Leftrightarrow c_{2} P-\lambda_{3} \gamma I+\lambda_{4} \gamma I=0 \\
& \Leftrightarrow P=\frac{\gamma I\left(\lambda_{3}-\lambda_{4}\right)}{c_{2}}
\end{aligned}
$$

\subsubsection{Simulasi}

Pada bagian ini akan ditampilkan kurva populasi tanaman terinfeksi terhadap waktu sebelum dilakukan pengontrolan maupun sesudahnya. Kurva tersebut ditinjau untuk pengendalian penyebaran hama kutu putih (Paracoccus marginatus) dengan pengontrolan terhadap jarak tanaman $\left(J_{T}\right)$ dan penyemprotan $(P)$. Kedua kurva tersebut berturut-turut dinyatakan pada Gambar 4.2 dan 4.3. Dalam menggambarkan kurva-kurva tersebut diperlukan nilai-nilai yaitu : $\psi_{K}=0,082, \mu_{K}=0,04, \alpha=0,07, \beta=$ $0,08, \gamma=0,02, \eta=0,02, \mu=0,02, K_{0}=1000, S_{0}=200, I_{0}=14, R_{0}=0$, di mana $\psi_{K}>$ $\mu_{K}, \beta+\gamma+\eta<1$, dan $\mu>0$.

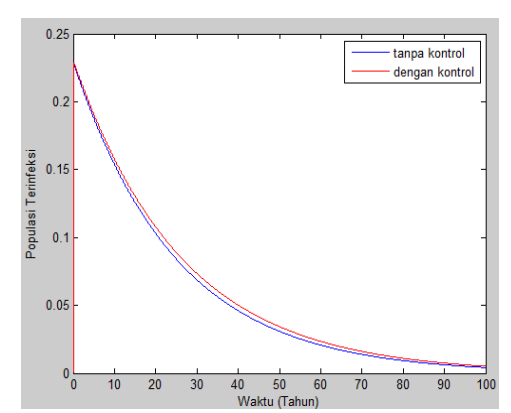

Gambar 2 : Populasi Tanaman yang Terserang Hama Kutu Putih (Paracoccus marginatus) dengan Kontrol Penyemprotan $(P)$

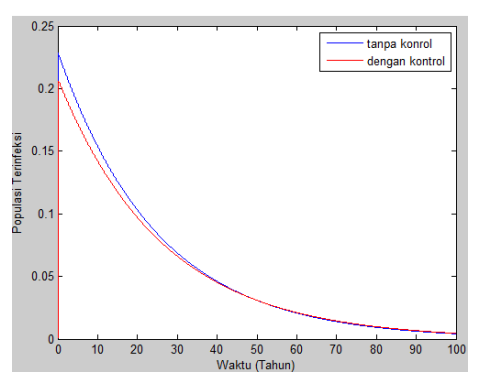

Gambar 3 : Populasi Tanaman yang Terserang Hama Kutu Putih (Paracoccus marginatus) dengan Kontrol Jarak Tanaman $\left(J_{T}\right)$ dan Penyemprotan $(P)$

\subsection{Pembahasan}

Hasil yang diperoleh pada sub bab3.1 memperlihatkan bahwa pengontrolan dengan hanya memakai kontrol penyemprotan $(P)$ saja, belum mampu menekan populasi tanaman yang terserang hama kutu putih (Paracoccus marginatus). Hal tersebut dapat dilihat pada Gambar 2, di mana populasi tanaman yang terserang kutu putih (Paracoccus marginatus) tanpa pengontrol di tampilkan dalam garis berwarna biru, sementara populasi yang tanaman 
terserang kutu putih (Paracoccus marginatus) dengan kontrol penyemprotan $(P$ ) ditampilkan dalam garis berwarna merah. Pengontrolan dengan penyemprotan $(P)$ populasi tanaman yang terserang hama kutu putih (Paracoccus marginatus) tidak menjadikan banyaknya populasi tanaman yang terserang kutu putih menjadi lebih sedikit meskipun tingkat pengontrolan sudah mencapai nilai parameter maksimum yang diizinkan, yaitu 0,9 . Nilai 0,9 ini berarti kontrol penyemprotan dilakukan pada $90 \%$ bagian dari pohon.

Pengontrolan dengan pengaturan jarak tanaman $\left(J_{T}\right)$ dan penyemprotan $(P)$ dapat menurunkan populasi tanaman yang terserang hama kutu putih (Paracoccus marginatus). Hal tersebut dapat dilihat pada Gambar 3, di mana populasi tanaman terserang kutu putih (Paracoccus marginatus) tanpa pengontrol di tampilkan dalam garis berwarna biru, sementara populasi tanaman terserang kutu putih (Paracoccus marginatus) dengan kontrol jarak tanam $\left(J_{T}\right)$ dan penyemprotan $(P)$ ditampilkan dalam garis berwarna merah. Pengontrolan dengan kontrol jarak tanam $\left(U_{T}\right)$ dan penyemprotan $(P)$ populasi tanaman terserang kutu putih (Paracoccus marginatus) dapat menurunkan banyaknya populasi tanaman yang terserang hama kutu putih meskipun dalam waktu 48 bulan usaha tersebut tidak lagi memberikan pengaruh. Setelah melampaui 48 bulan banyaknya populasi tanaman yang terserang hama kutu putih adalah sama dengan maupun tanpa pengontrolan meskipun pengaturan jarak tanaman dan penyemprotan sudah mencapai tingkat maksimum yang diizinkan, yaitu 0,9. Nilai 0,9 ini berarti kontrol penyemprotan dilakukan pada $90 \%$ bagian dari pohon dan $90 \%$ dari jarak tanaman.

\section{KESIMPULAN}

Berdasarkan penelitian yang telah dilakukan, maka dapat disimpulkan bahwa :

1. Pengontrol optimal dari model pengendalian penyebaran hama kutu putih (Paracoccus marginatus) paling baik dari 2 (dua) pengontrolan yang dilakukan adalah dengan melakukan pengontrolan dengan kombinasi kontrol jarak tanaman $\left(J_{T}\right)$ dan penyemprotan $(P)$.

2. Pengontrol optimal dari model pengendalian penyebaran hama kutu putih (Paracoccus marginatus) ditentukan dengan

a. Membangun performance index untuk meminimumkan jumlah tanaman yang terseranghama kutu putih (Paracoccus marginatus).

b. Menyelesaikan persamaan kontrol optimal yang dilakukan dengan menentukan fungsi Hamiltonian.

c. Fungsi Hamiltonian memberikan persamaan state, co-state dan kondisi stasioner. Dengan menyelesaikan persamaan-persamaan tersebut, diperoleh kontrol optimal untuk parameter $P$ dengan menggunakan kontrol penyemprotan $(P)$ yaitu $P(t)=$ 
$\min \left\{\operatorname{maks}\left(0,1,\left(\frac{\gamma I R\left(\lambda_{3}+\lambda_{4}\right)}{c_{1}}\right)\right), 0,9\right\}$. Sedangkan untuk parameter kontrol jarak tanaman $\left(J_{T}\right)$ dan kontrol penyemprotan $(P)$ diperoleh $J_{T}(t)=\min \left\{\operatorname{maks}\left(0,1,\left(\frac{\beta S\left(\lambda_{3}-\lambda_{2}\right)}{c_{1}}\right)\right), 0,9\right\}$ $\operatorname{dan} P(t)=\min \left\{\operatorname{maks}\left(0,1,\left(\frac{\gamma \operatorname{IR}\left(\lambda_{3}-\lambda_{4}\right)}{c_{2}}\right)\right), 0,9\right\}$.

d. Mensubtitusi kontrol optimal yang diperoleh kedalam persamaan state.

2. Pengendalian tidak lagi memberikan pengaruh terhadap penurunan populasi tanaman yang terserang hama kutu putih setelah 48 bulan, meskipun tingkat penyemprotan dan pengaturan jarak tanaman sudah maksimum yaitu $90 \%$.

\section{DAFTAR PUSTAKA}

[1]. Amarasekare, K.G., C.M. Mannion, L.S. Osborne, and N.D. Epsky. 2008. Life History of Paracoccus marginatus (Hemiptera: Psudococcidae) on four host plant spesies under Laboratory Condition. Environ. Entomol.37(3): 630- 635.

[2]. Bellamo, N. and Preziosi, L. 1995. Modelling Mathematical Methods and Scientific Computation.CRC Press, Inc, Florida.http://win.staff.uns.ac.id/files/2009/02/sir_routhhurwitz.pdf. [20 Februari 2014].

[3]. CABI. 2005. Crop Protection Compendium. CAB International, Wallingford.

[4]. Deffan, P. 2010. Invasi kutu dari Meksiko. Koran Tempo. http://www.google.co. id/search?hl=id\&source=hp\&q=paracoccus+in+indonesia\&meta=\&aq=o\&aqi=\&aql=\&oq=\&gs_rfai. [19 Februari 2014].

[5]. Hethcote, H.W. 2000. The Mathematics of Infectious Disease.SIAM REVIEW, 42, 599-653.

[6]. Heu, R.A., M.T. Fukada, and P. Conant. 2007. Papaya Mealybug Paracoccus marginatus Williams and Granara de Willink (Hemiptera : Pseudococcidae). State of Hawaii New Pest Advisory Department of Agriculture. No. 04-03.

[7]. Idayani Darsih, 2010, Kendali Optimal Pada Pengadaan Barang Mentah Dengan Kebijakan Pengadaan Tepat Waktu, Pergudangan, dan Penundaan, ITS, Surabaya.

[8]. Kermack, W. O. and McKendrick, A. G., 1927. A Contribution to theMathematical Theory of Epidemics, Royal Society, 115: 700-721.

[9]. Miller DR, GL. Miller. 2002. Redescription of Paracoccus marginatus Williams and Granada de Willink (Hemiptera: Coccidae: Pseudococcidae), including descriptions of the immature stages and adult male. Proc. Entamol. Soc.wash.104(1): 1-23.

[10]. Naidu, D. S. 2002. Optimal control system, USA: CRC Presses LLC.

[11]. Pramayudi Nur, Hartati Oktarina, 2012,Biologi Hama Kutu Putih Pepaya (Paracoccus marginatus) pada Tanaman Pepaya, Universitas Syiah Kuala Darussalam Banda Aceh, Aceh.

[12]. Sartiami, D., Dadang, R. Anwar, dan I.S. Harahap, 2009a, Persebaran hama baru Paracoccus marginatus di Provinsi Jawa Barat (Abstrak), Dalam Buku Panduan Seminar Nasional Perlindungan Tanaman, Bogor.

[13]. Tu, P. N. V. 1994. Dynamical System An ntroduction with Application in Economics and Biologi, Springer-Verlag,Germany. 
[14]. Walker A, Hoy M, and Meyerdirk D. 2003. Papaya mealybug (Paracoccus marginatus Williams and Granada de Willink (Insecta: Hemiptera: Pseudococcidae). Featured creatures.Institut of Food and Agricultural Sciences, University of Florida. 